\title{
S5ynthesis
}

International Scientific Conference of IT and Business-Related Research

\section{PRIMENA RAČUNARSKIH SISTEMA U MODNOJ INDUSTRIJI SA TENDENCIJOM PRILAGOĐAVANJA UNIKATNIH MODELA SERIJSKOJ PROIZVODNJI}

\author{
THE USE OF COMPUTER SYSTEMS IN FASHION INDUSTRY \\ FOR THE PURPOSE OF PREPARING UNIQUE MODELS FOR MASS PRODUCTION
}

\author{
Marina Kocareva Ranisavljev ${ }^{1}$, Mirjana Reljićc ${ }^{2}$, Nikola Maksimović \\ ${ }^{1}$ Univerzitet Singidunum, Danijelova 32, Beograd \\ ${ }^{2}$ direktor CIS Instituta, Beograd
}

\begin{abstract}
Apstrakt:
Analiza inovativnih postupaka i strategija u dizajnu, menadžmentu i marketingu u modnoj industriji potvrđuje mogućnost daljeg razvoja kroz primenu visokih tehnologija, sa akcentom na elektronici i digitalnoj tehnologiji. Na pitanje od kojih se novih tehnologija očekuje da će izazvati revoluciju u modnoj industriji na globalnom planu i na koji način, odgovor je prilično složen. Naglasak je pre svega na onim tehnologijama koje omogućavaju proizvodu da održi svoj digitalni identitet na zavidnom nivou, uključujući i distribuciju proizvoda. Činjenica je da Internet kao globalna mreža predstavlja značajno sredstvo komunikacije, koje prenosi bitne informacije o proizvodu na globalnom nivou. Razvoj digitalnog dodira i digitalizovanog mirisa pružiće klijentima sve neophodne informacije pri kupovini i izboru odevnog predmeta, bez prethodnog fizičkog kontakta sa uzorkom. Naime, sama proizvodnja mora da postane proces prelaska iz digitalnog ka fizičkom.

Kroz interdisciplinarnost i sintezu novih materijala, novih tehnologija i dizajna, uključujući i komercijalni aspekt, rad ukazuje na nove puteve, metode i donosi zaključke da su koncept i kvalitet dizajna u svakom aspektu od presudnog značaja za buduća istraživanja i napredak u modnoj industriji.
\end{abstract}

\section{Ključne reči:}

modna industrija, digitalne tehnologije, digitalna izrada krojnih slika, 3D simulacija modela.

\section{UVOD}

Razvoj tehnološkog proizvodnog sistemama u modnoj industriji doveo je do značajnih promena u pogledu globalne industrijske automatizacije. Intenzivno ulaganje u proizvodni sistem i atomatizaciju omogućava opstanak proizvodnih baza u dužem vremenskom periodu, kao i konkurentnost samih proizvoda. Dizajn/razvoj proizvoda, prodaja/marketing, proizvodnja i isporuka predstavljaju četiri glavna koraka u lancu snabdevanja odevnim proizvodima i prostor $\mathrm{u}$ kome digitalne tehnologije imaju potencijal da se razviju unutar svake od navedenih oblasti. Primena 3D alata u dizajnu i razvoju proizvoda omogućava virtuelno stvaranje modela 3D tehnologijom, kao i automatsko konvertovanje u 2D tradicionalne metode proizvodnje. Digi-

\section{Abstract:}

The analysis of innovative procedures and strategies used in design, management and marketing in the fashion industry indicates the possibility of further development through application of high-technology, with a special emphasis on electronics and digital technology. The answer to the question regarding the type of technology that is expected to cause breakthrough in the fashion industry at the global level, is rather complex. The emphasis is primarily on those technologies that allow the product to maintain its original digital identity at a high level, including the product distribution. It is well-known that the Internet as a global network represents an important means of communication, which conveys important information about the product on a global scale. The development of 'digital touch' and 'digital smell' will provide customers with necessary information when choosing and purchasing an item of clothing, without prior physical contact with the sample. Namely, the production itself must become a process of conversion from digital to physical. The product should assume physical form at some point, but such process is quite tedious and time-consuming. Through interdisciplinarity and synthesis of new materials, the latest technologies and designs, including the commercial aspect, the paper reveals the new ways and methods, and reaches the conclusion that the concept and design quality are of vital importance for future research and advancement in the fashion industry.

\section{Key words:}

fashion industry, digital technologies, digital pattern design, 3D model simulation.

talizacija u skeniranju tela i virtuelnom prikazu modela odeće, koji uključuje i simulaciju karakteristika tkanine, omogućava digitalno praćenje procesa razvoja konstrukcije, bez potrebe za fizičkim uzorkom. Unutar distribucije i marketinga digitalne tehnologije omogućavaju predstavljanje koncepata i projekcija, kao i detaljan prikaz oblika i performansi proizvoda.

U radu je predstavljena tendencija povezivanja eksperimentalnog/analitičkog dizajna sa industrijskim proizvodnim sistemom, odnosno prilagođavanje unikatnih modela odeće industrijskim proizvodnim procesima i automatizaciji. $U$ tu svrhu odabran je model šifra 28046 - transponovanje elemenata oficirskog paradnog mundira u formu ženskog kaputa.

Istarživanje kreće od manjih transformacija unutar kroja i elemenata muškog vojnog kaputa i njegovog transponovanja u ženski odevni predmet po principu cross-dressinga. 
Eksperimentalni deo istraživanja, kroz realizaciju različitih projekata, otkriva dekonstruktivistički pristup modnom dizajnu i tendenciju preispitivanja ustaljenih kanona u okviru modne prakse i modnog sistema. Standardizacija i multiplikacija, kao oblici industrijalizacije, prevazilaze se, upravo, postupkom dekonstrukcije, permutacijom znakova i značenja. Iskorak od standardnih ka postmodernim formama uočava se u resemantifikaciji i dekonstrukciji vojne uniforme. Inkorporacijom visokih tehnologija, primenom novih materijala, konceptualnim pristupom dizajnu i modnoj prezentaciji otvaraju se novi prostori i metode istraživanja.
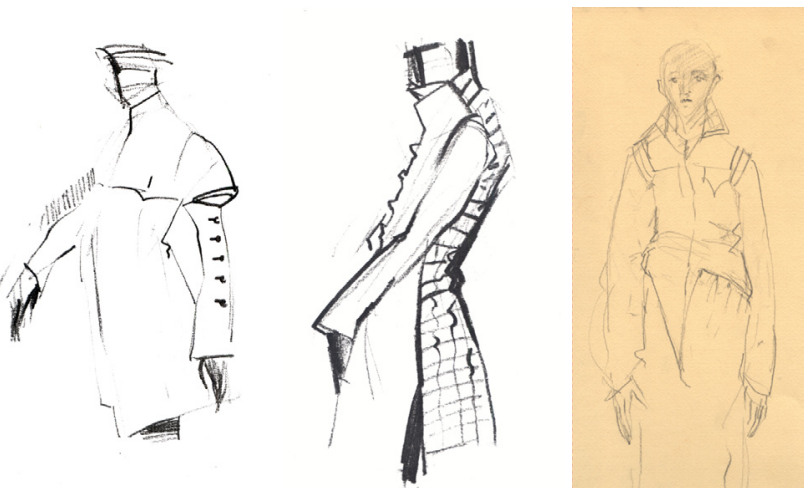

Slika 1. Marina K. Ranisavljev, idejne skice realizovanih modela, 2011.

\section{DEKONSTRUKCIJA PROCES ANALITIČKOG STVARANJA}

Dekonstrukcija, kao filozofska praksa, ima daleko širi uticaj van granica filozofije i akademskih spekulacija. Od svoje rane popularizacije šezdesetih godina XX veka prešla je različite oblasti, od literature, filma, arhitekture do svih oblasti dizajna. Ali i pre nego što je sama reč dekonstrukcija počela da cirkuliše u modnom svetu, postalo je jasno da neki dizajneri već reaguju i suprotstavljaju se okvirima dominantne mode. Pojava nove generacije avangardnih dizajnera na modnoj sceni početkom osamdesetih godina XX veka nagovestila je neku vrstu "pretnje" u odnosu na postojeći modni sistem (Loscialpo, 2009). Pod uticajem minimalizma, sopstvene kreativnosti i kulture, dizajneri Rei Kavakubo (Rei Kawakubo), Jođi Jamamoto (Yohji Yamamoto), Isei Mijake (Issey Miyake), a krajem decenije i belgijski kreator Martin Margiela, začeli su ono što se legitimno može smatrati modnom revolucijom. Primenom dekonstrukcije ovi dizajneri su potpuno razorili strukturu odeće i otkrili nove mehanizme fascinacije ove "preteće" mode (Suđić, 1990). Baš kao u filozofskoj ili u arhitektonskoj praksi, dekonstrukcija kojoj su težili modni dizajneri bila je predodređena da stvara novu konstrukciju, kao i nove mogućnosti značenja, ali i da dovede u pitanje tradicionalno shvatanje, šta je ispod a šta preko, šta ispred a šta iza, šta je nevidljivo, a šta samo neviđeno. Da bi to postigli, oni su ponovo razmotrili i pomerili parametre koji određuju, šta je na vrhu ili na dnu modne lestvice, što je izazvalo otvoreno suprotstavljanje neistomišljenika.

Prema modnim stručnjacima, 1981. je godina u kojoj su Jođi Jamamoto i Rei Kavakubo po prvi put prikazali svoje kolekcije u Parizu. Njihova pojava primorala je predstavnike svetskih medija da preispitaju svoje stavove (Baudot, 1997). Odbacujući svaki kliše u shvatanju pojma glamur kao i kako bi trebalo da izgleda modna silueta, oni ukazuju na novi pristup odevanju u post-industrijskom društvu kasnog XX veka.

Radeći na dekonstrukciji dizajneri su se, više od dve decenije, neprestano suočavali sa granicama koje su određivale i još uvek određuju modu i dan- danas. Njihov rad, u stvari, predstavlja reakciju i kritički osvrt na tradicionalne krojačke metode. Ono što dekonstruktivna moda želi da prikaže jeste kako odsustvo, dislokacija i umnožavanje utiču na vezu između individualnog tela i njegove zamrznute idealizacije. Značajno je to da je ranih osamdesetih rad dizajnera koji su se bavili dekonstrukcijom, smatran direktnim napadom na ideje Zapada o obliku tela. Njihovi dizajnerski radovi, vidno bezoblični, bili su radikalno nepoznati. Taj novi "bezobličan" oblik suptilno je pretio propisanim parametrima i prenaglašenoj silueti aktuelne mode tog vremena (Wilson, 1985). Dekonstruktivna moda izazvala je tradicionalnu suprotstavljenost između "subjekta" i "objekta“, unutrašnjeg i spoljašnjeg. Konačno se ispostavilo da subjektivnost nije datost, već je pre kontinuirano artikulisana, kroz vreme i prostor, prema različitim mitovima, potrebama, tvrdnjama i negacijama.

Princip modne dekonstrukcije prepoznatljiv je ne samo u narušenoj strukturi specifičnih odevnih komada, u nedovršenosti, u postupku oduzimanja, umnožavanja ili premeštanja odevnih elemenata, već pre svega u preispitivanju funkcije i značenja same odeće. Postupak dekonstrukcije otvara prostor za nove modne polemike, dovodeći u pitanje odnos između tela i odeće, kao i koncept "tela" samog po sebi. Potpuna sloboda u dekomponovanju elemenata prilikom stvaranja nove forme otkriva uvek nove horizonte (Kocareva Ranisavljev, 2012).

\section{PRIMENA RAČUNARSKOG SISTEMA}

Trodimenzionalni kompjuterski dizajn je postao jedan od najvažnijih elemenata odevne industrije. Vrlo je teško pronaći bilo kakav proces dizajniranja koji nije potpomognut CAD sistemima u tradicionalnim proizvodnim procesima mašinstva, avio-industrije i vodo-industrije, tako da ga danas mnogi inženjeri uzimaju kao neophodan deo svakog procesa (Lee, 1999). Naravno, ovaj trend se prihvata i u odevnoj industriji. Međutim, $2 D C A D$ sistemi su još uvek preovlađujući tako da je teško $3 \mathrm{D}$ dizajniranje odeće. Ovo je delimično posledica činjenice da postoje poteškoće prilikom matematičkog modelovanja materijala tkanine. Međutim, još veći problem je to što dizajneri i ljudi koje se bave pravljenjem uzoraka misle da CAD metod nije bolji od konvencionalne ručne metode (Stjepanović, 1995; Aldrich, 1992). Iako se ovaj fenomen pojavljivao prilikom početnog stadijuma razvoja drugih namena CAD sistema, on je još ozbiljniji i prirodniji u odevnoj industriji, jer procena kvaliteta proizvoda više zavisi od ljudskog estetskog osećaja nego od optimalne fizičke performanse. Naravno da postoje odevni predmeti kojima funkcionalno treba više od estetskog izgleda, kao što je uski donji veš ili zaštitna odeća, tako da će CAD sistemi biti moćno oružje za proizvodnju i dizajniranje takvih odevnih predmeta.

Postoje dva osnovna metoda za stvaranje uzoraka u konvencionalnom odevnom dizajnu. Jedan je proces ravnog uzorka, gde se uzorci dizajniraju dvodimezionalno, dok je drugi metod 3D nabiranja, gde se ravna tkanina direktno formira na odevni predmet na lutki. Iako je teže dobiti uzorke odeće ovim drugim metodom, on je mnogo pogodniji za dobijanje dobro pristalih uzoraka pa su se zato i istraživanja fokusirala na njega. $U$ tom slučaju, potrebne su linije reza koje se nazivaju ušitci ako odeća ima nerazvijene zakrpe. McCartney i ostali pokušali su da stvore 3D površine pomoću ušitaka i da primene te tehnike prilikom stvaranja uzoraka (McCartney et al., 1999; Collier \& Collier, 1990; Heisey et al., 1990b). Međutim, u tom slučaju se nije moglo doći do potpunih podataka sa 3D modela ljudskog tela, pa je bilo teško stvarati praktične odevne uzorke. Nedavno su, usled razvitka tehnologije merenja bez kontakta, podaci sa 3D ljudskog tela postali dostupni i urađeno je mnogo studija 
vezanih za ovu temu (McCartney et al., 2000; Daanen \& Water, 1998; Au \& Yuen, 1999; Paquette, 1996). Kim et al. su pokušali da stvore uzorke odeće kombinovanjem podataka sa 3D ljudskog modela i odevnog modela. Oni su takođe razvili i sistem za interaktivno dizajniranje uzorka pomoću modela tela koji se može parametarski menjati iz podataka dobijenih 3D skeniranjem ljudskog tela (Kim \& Park, 2004; Kim \& Kang, 2002). Međutim, bilo je problema vezanih za činjenicu da je teško dobiti idealan oblik odeće takvim metodama, već se mogu dobiti samo osnovni uzorci. U ovoj studiji, odeća je podeljena na dve oblasti, jedna predstavlja oblast pristalosti, a druga oblast mode. Oblast pristalosti se modeluje digitalizovanjem podataka dobijenih skeniranjem ljudskog tela tako da se može dobiti optimalna pristalost kao i idealan oblik odeće. Oblast pristalosti se može preoblikovati i može joj se menjati veličina pomoću osnovnih antropometričkih parametara tako da se oblasti pristalosti različitih veličina mogu modelovati iz podataka dobijenih iz jednog skenera ljudskog tela. Oblast mode se modeluje pomoću parametara koji određuju estetski izgled odeće tako da korisnici mogu intuitivno dizajnirati odevne predmete sa raznim siluetama. Na kraju, algoritam projekcije ravnog uzorka je razvijen kako bi se napravili komadi ravnog uzorka iz trodimenzionalno modelovane odeće uzimajući u obzir fizičke osobine kao i produktivnost tkanine.

\section{EKSPERIMENTALNI DEO: KONSTRUKCIONA PRIPREMA MODELA 28046 PARADNI KAPUT - MUNDIR}

Postupak konstrukcione pripreme modela izveden je na računarskom sistemu Lectra, a krojni delovi obrađeni su u programima Modaris i Diamino. Modaris je korišćen kao podrška za konstrukciju, modelovanje i kompletiranje krojeva, a Diamino za uklapanje krojnih slika.

Sva tri modela modelirana su u veličini obima grudi $=88$ $\mathrm{cm}$, prema standardu SRPS EN 13402-3: 2007. Za modeliranje krojnih delova modela košulja 26217 i 26218 korišćena je osnovna konstrukcija ženske košulje, a za model mundira korištena je osnovna konstrukcija ženskog kaputa. Primenjene metode modelovanja omogućile su da se brzo postigne željena forma modela kao i da se postigne velika preciznost u radu.

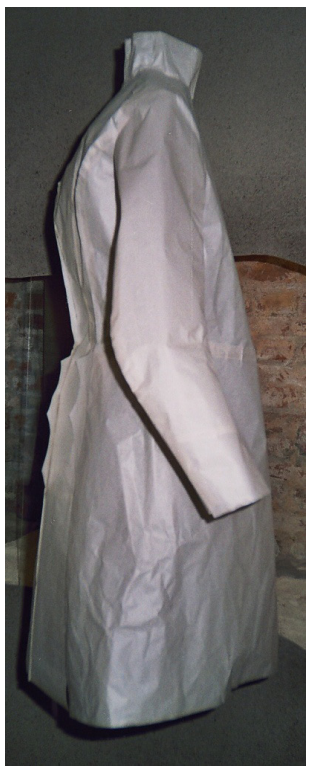

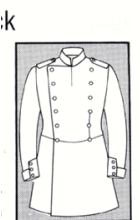
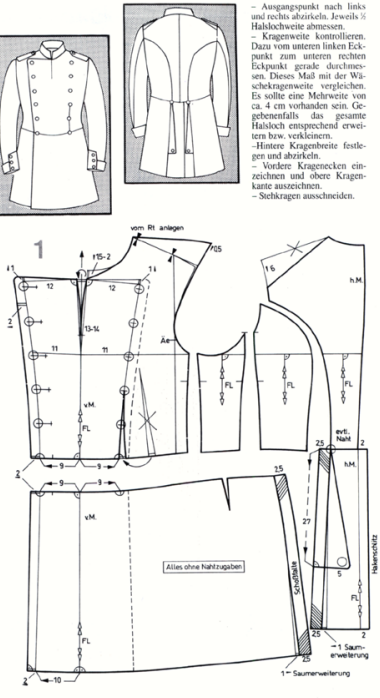
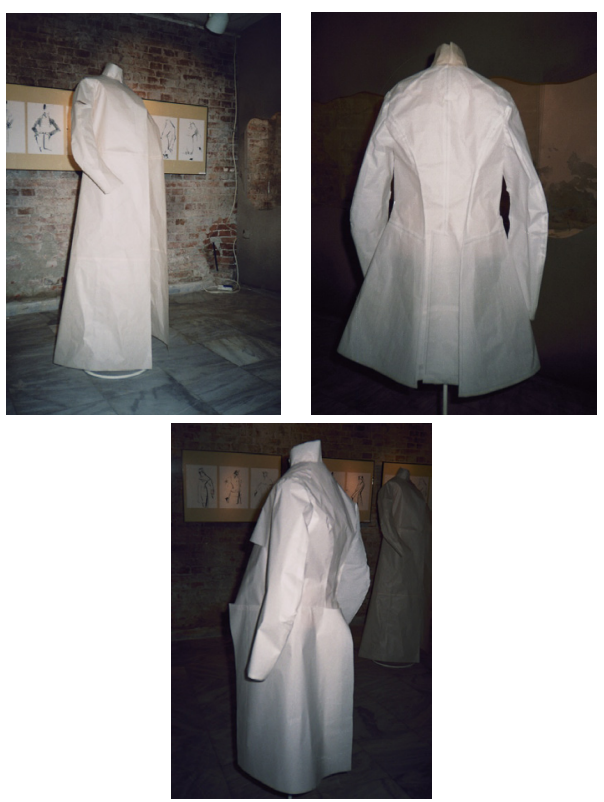

Slika 2. Otvoreni kroj i rekonstrukcije bazičnog modela vojnog mundira Izvor: Kocareva Ranisavljev, M. Izložba Muzeja primenjene umetnosti, Beograd
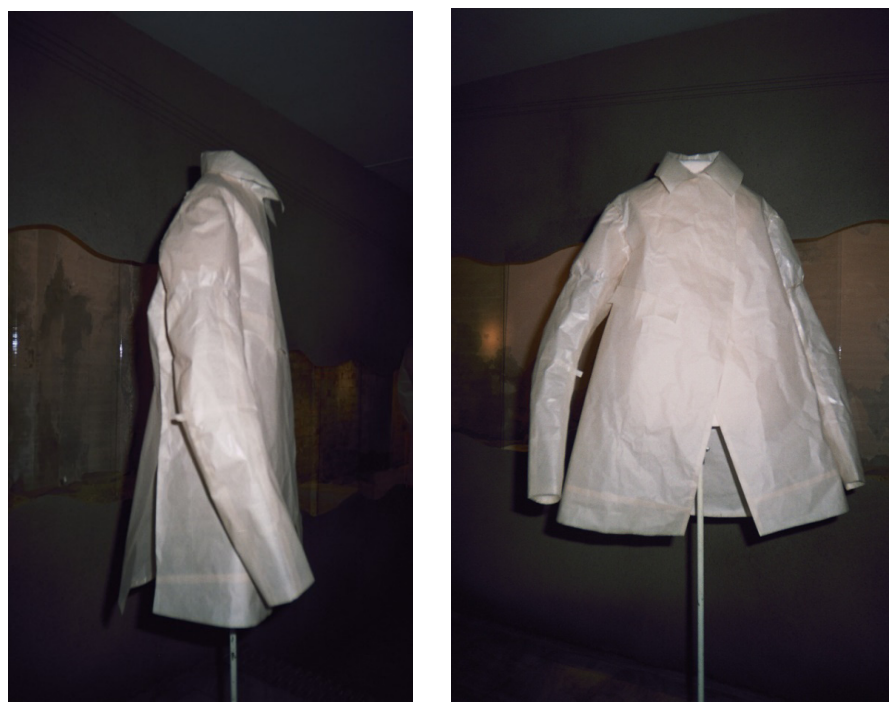

Slika 3. Transponovane forme paradnog kaputa - mundira izvedene u papiru. Izvor: Kocareva Ranisavljev, M. (2010) 

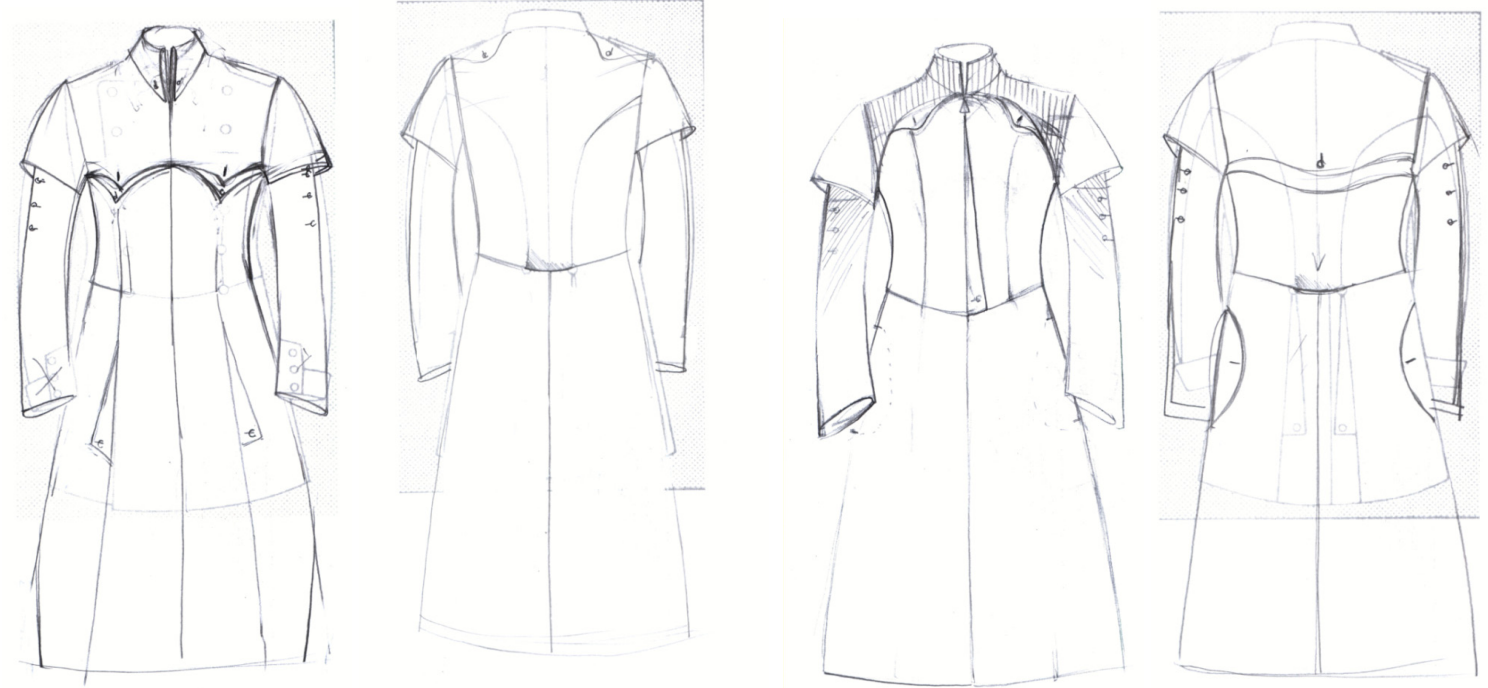

Slika 4. Levo - tehničke skice modela 28046: transponovani model mundira;

Slika 4. Desno - tehničke skice modela: transponovani model mundira (varijanta b).

Izvor: Kocareva Ranisavljev, M. (2014)

Slika 5 (model 28046) predstavlja modeliranje svih krojnih delova kaputa i formiranje varijante. Na slici 6 (opis modela) prikazana je varijanta modela u kojoj su sadržani svi pripadajući krojni delovi kaputa sa definisanjem kroja delova, tj. simetrije i asimetrije u kroju. Ostale slike (Sl. 7, Sl. 8, Sl. 9) predstavljaju krojne slike osnovnog materijala, postave i lepljive međupostave.

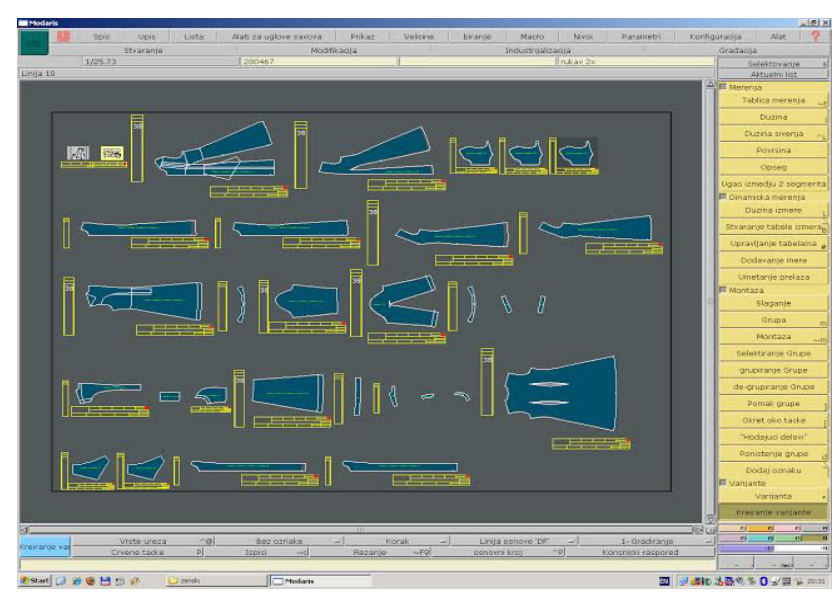

Slika 5. Modeliranje kroja ženskog kaputa - model 28046

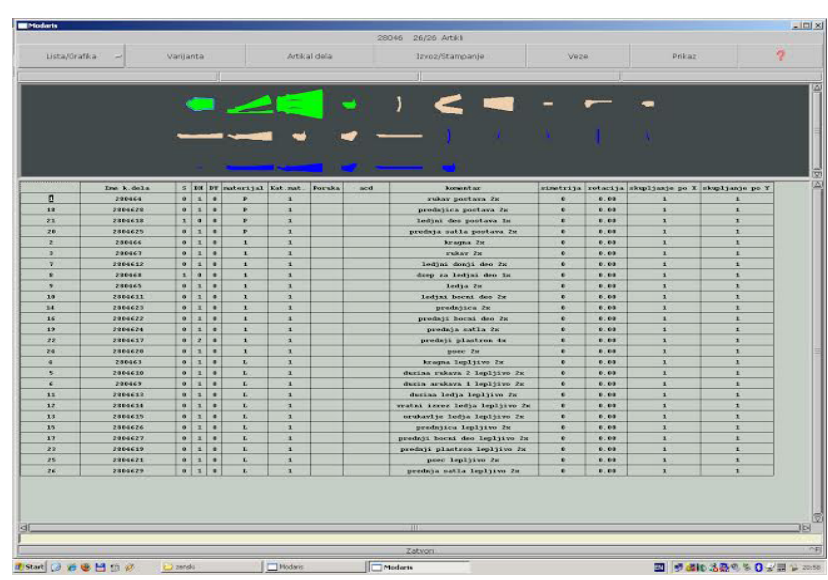

Slika 6. Spisak svih krojnih delova i kompletiranje potrebnog broja krojnih delova - model 28046

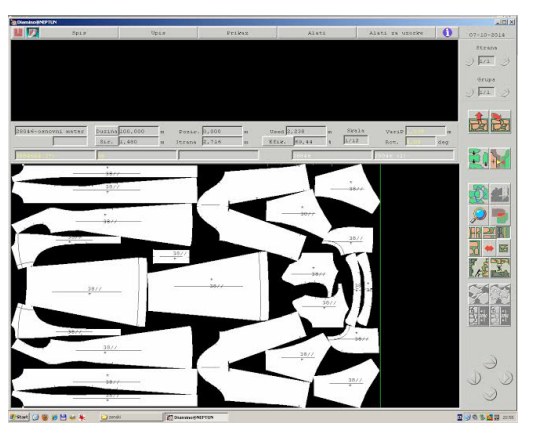

Slika 7. Krojna slika za osnovni materijal- model 28046

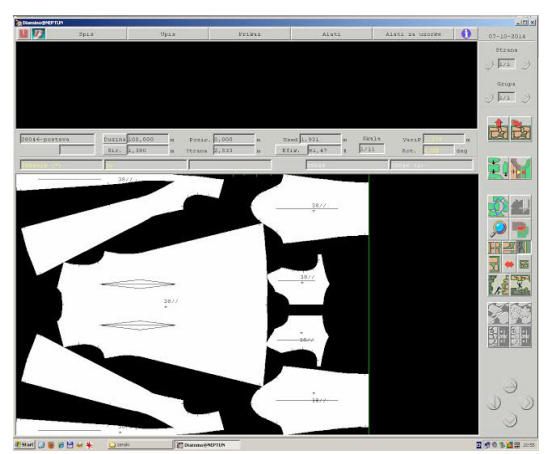

Slika 8. Krojna slika za postavu - model 28046

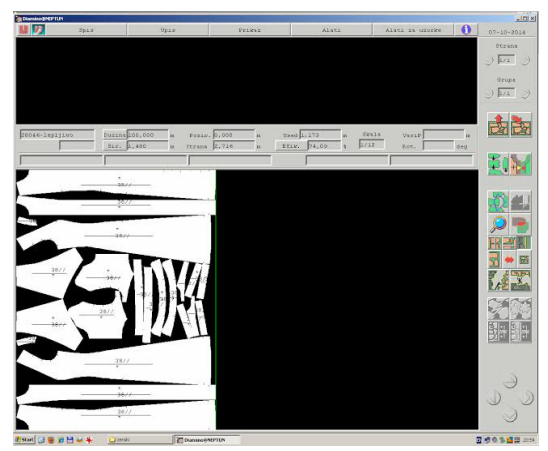

Slika 9. Krojna slika za lepljivu međupostavu- model 28046 


\section{3D VIRTUELNI MODEL: RAZVOJ KROJA PRIMENOM 2D KROJNIH SLIKA}

Za 3D simulaciju modela 26218 korišćen je savremeni specijalizovani CAD/CAM programski paket Optitex (PDS) za dizajn, konstrukciju i proizvodnu pripremu u okviru odevne industrije. Sam princip rada podrazumeva da se za simulaciju upotrebljavaju autentični digitalizovani krojni delovi, korišćeni za izradu konkretnog odevnog predmeta u ovom slučaju kaputa transponovanog iz vojne uniforme, odnosno paradnog mundira.

Ovom prilikom vršena je autentifikacija i validacija već izrađenog odevnog predmeta, međutim, proces može krenuti i iz smera izvornog dizajna. Sam zadatak programa predstavlja virtuelno šivenje proizvodnih, realnih $2 \mathrm{D}$ krojnih delova odevnog predmeta u virtuelni 3D odevni predmet. Prilikom procesa simulacije u program se unose različiti parametri za kalkulacije, neki od najbitnijih su telesne mere virtuelnog manekena, fizičke karakteristike tekstilnog materijala koji je namenjen za izradu odevnog predmeta, kao što su vrsta materijala, njegova elastičnost i rastegljivost, pregibanje, koeficijent trenja, težina, debljina, gustina, transparentnost. Slični parametri, takođe, određuju se i za konac, dugmiće i druge elemente koji ulaze u kalkulaciju simulacije.

Nakon određivanja potrebnih parametara, vrši se pozicioniranje i prilagođavanje krojnih delova u zavisnosti od mesta gde se nalaze u okviru odevnog predmeta. Radi verodostojnijeg prikaza na modelu se mogu primeniti različite vrste tekstura materijala i elemenata odevnog predmeta. Nakon unosa svih neophodnih parametara otpočinje proces simulacije i programski algoriram počinje da primenjuje unete parametre kojima dodaje još i virtuelnu silu gravitacije u cilju što realnije virtuelne realizacije modela. Nakon nekoliko minuta simulacija je završena, i tada se može vršiti vizuelna inspekcija modela, korekcije i modifikacije. Sam model moguće je izvesti iz programa i preneti ga u različite standardne grafičke i 3D formate pomoću kojih je
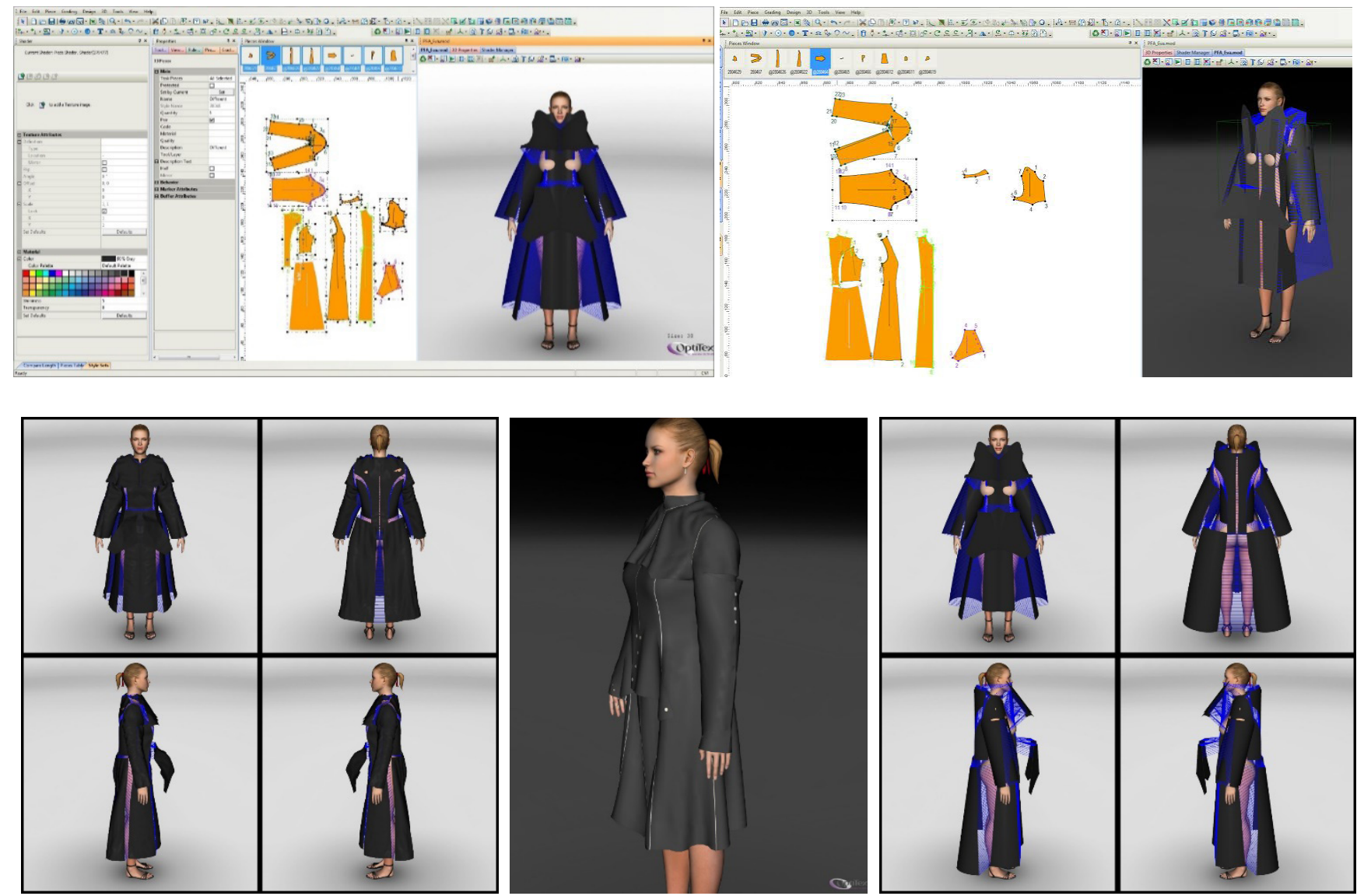

Slika 10. Razvoj kroja primenom 2D krojnih slika
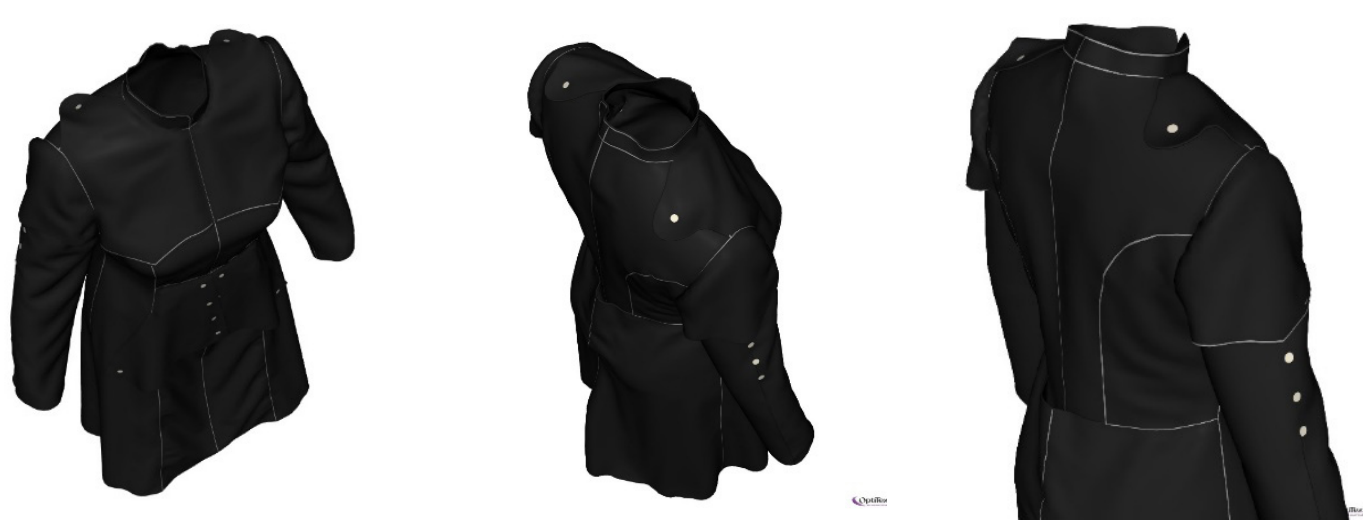

Slika 11. 3D virtuelni model : prikaz iz različitih perspektiva 
moguće jednostavno razmenjivati mišljenja i ideje ili organizovati marketinške delatnosti.

\section{ZAKLJUČAK}

Suština eksperimentalnog dela istraživanja metodom praktičnog rada jeste prikazati mogućnost prevođenja ideje/koncepta u realan tržišni proizvod, odnosno, mogućnost transponovanja unikatnog odevnog predmeta u predmet masovne industrijske proizvodnje primenom savremenih (inženjerskih) digitalnih tehnologija u okviru modne industrije i modnog dizajna. $U$ tom cilju istraživanje u okviru praktičnog dela kreće od same idejne skice i likovnog predstavljanja projekata, što uključuje i različite načine modnih prezentacija (izložbe, modne performanse, modne revije), sa akcentom na konceptu i kontekstu, da bi se na kraju, primenom digitalnih tehnologija i računarskih sistema, došlo do komercijalnog tržišnog proizvoda prilagođenog pretaporteu i masovnoj proizvodnji odeće. Primena digitalizacije, $C A M / C A D$ računarskih sistema u procesima dizajniranja i proizvodnje, uključujući i 3D animacije i virtuelno predstavljanje dizajna omogućava lako i veoma brzo prevođenje ideja, oblika, materijala u tržišni proizvod, koji se može virtuelno predstaviti, korigovati i promovisati i pre same realizacije.

Kroz interdisciplinarnost i sintezu novih materijala, novih tehnologija i dizajna, uključujući i komercijalni aspekt, istraživanje otkriva nove puteve i metode i zaključke da su koncept i kvalitet dizajna u svakom aspektu od presudnog značaja za buduća istraživanja i napredak stvaralaštva.

Analiza inovativnih postupaka i strategija u dizajnu, menadžmentu i marketingu u modnoj industriji potvrđuje mogućnost daljeg razvoja kroz primenu visokih tehnologija, sa akcentom na elektronici i digitalnoj tehnologiji. U tom smislu, budućnost implementacije novih tehnologija u modnom dizajnu i modnoj industriji može se sagledati sa više aspekta.

Sa aspekta industrijalizacije, automatizacije i omasovljenja, u tom kontekstu zaključuje se sledeće:

- Primena računarskih sistema i digitalizacije u okviru dizajn procesa, kao i mogućnost skeniranja tela, beleženja i elektronskog transporta ličnih telesnih podataka nagoveštava napuštanje tradicionalnih sistema dizajniranja, proizvodnje, distribucije i prodaje.

- U novom društvenom kontekstu na pragu novog milenijuma postaju sporni sama priroda materijala, kao i način stvaranja i prevođenja u odevni predmet.

- Savremena otkrića u postmodernom dobu nagoveštavaju potpuno nove metode u modnoj industriji, između ostalog masovnu proizvodnju u kojoj će se tradicionalni način oblikovanja zameniti direktnom izradom u tri dimenzije ( $3 D$ printing).

- Tradicionalan postupak u izradi tkanina i odeće, prema budućim vizijama, primenom visokih tehnologija ustupiće mesto odeći sazdanoj direktno iz tečnosti ili praha, čak iz skupova atoma koji se mogu ponovo organizovati po želji.

- 3D izrada zahteva radikalno preispitivanje modne industrije. Stvaranje "instant odeće" od praškastih polimera koji se vezuju uz pomoć lasera, može postati ozbiljna konkurencija šivaćoj mašini.

- Postindustrijska vizija ima potencijal da se otrgne od tradicionalnog načina stvaranja, a ujedno i da preoblikuje želje potrošača. Na pragu XXI veka radikalne tehnologije spremne su da redefinišu tradicionalno shvatanje dizajna, proizvodnje i potrošnje postmoderne mode.
Implementacija novih tehnologija i metoda u modnom dizajnu i modnoj industriji uslovljava potpunu reorganizaciju modnog sistema, primenu novih poslovnih strategija u poslovnoj politici modne industrije, kao i na globalnom tržištu u periodu postmoderne mode.

\section{LITERATURA}

Aldrich, W. (1992). CAD in clothing and textiles: A collection of expert views. Oxford: Blackwell Scientific Publications.

Au, C., \& Yuen, M. (1999). Feature-based reverse engineering of mannequin for garment desing. Computer-Aided Design, 15(1), 751-759.

Baudot, F. (1997). Yohji Yamamoto. London: Thames and Hudson.

Collier, B. \& Collier, J. (1990). CAD/CAM in the textile and apparel industry. Clothing Textile Research Journal, 8(3), 7-12.

Daanen, H., \& Water, G. (1998). Whole body scanners. Displays, 19(3), 111-120.

Guerrero, J. A. (2010). New fashion and design technologies. London: A\&C Black.

Heisey, F., Brown, P., \& Johnson, R. (1990a). Three-dimensional pattern drafting, part 1: projection. Textile Research Journal, 60(11), 690-696.

Heisey, F., Brown, P., \& Johnson, R. (1990b). Three-dimensional pattern drafting, part 2: garment modeling. Textile Research Journal, 60(12), 731-737.

Kim, S., \& Kang, T. (2002). Garment pattern generation from body scan data. Computer-Aided Design, 35, 611-8.

Kim, S., \& Park, C. (2004). Parametric body model generation for garment drape simulation. Fibers and Poliymers, 5(1), 12-18.

Kocareva Ranisavljev, M. (2012). Moda i dekonstrukcija. Beograd.

Kocareva Ranisavljev, M. (2011). Moda i odevanje : psihosociološki aspekti odevanja. Beograd: Službeni glasnik.

Lee, K. (1999). Principles of CAD/CAM/CAE systems. Reading, Mass: Addison-Wesley.

Loscialpo, F. (2009). Fashion and Philosophical Deconstruction: a Fashion In-Deconstruction. Copenhagen Working Papers on Design. Copenhagen: The Danish Design School.

McCartney, J., Hinds, B., \& Seow, B. (1999). The flattening of triangulated surfaces incorporating darts and gussets. Computer-Aided Design, 31(4), 249-260.

McCartney, J., Hinds, B. Seow, B., \& Dong, G. (2000). An energy based model for the flattening of woven fabrics. Journal of Materials Processing Technology, 107(19), 312-318.

Paqette, S. (1996). 3D scanning in apparel design and human engineering. IEEE Computer Graphics and Aplications, 16(5), 11-15.

Stjepanovic, Z. (1995). Computer-aided processes in garment production. International Journal of Clothing Science \& Technology, 7(2), 81-88.

Sudjic, D. (1990). Rei Kawakubo and Comme des Garçons. New York: Rizzoli.

Wang. C.C.L., Wang, Y., Tang, K., \& Yuen, M.M.F. (2004). Reduce the stretch in surface flattening by finding cutting paths to the surface boundary. Computer Aided Design, 30, 665-677.

Wilson, E. (1987). Adorned in dreams: Fashion and modernity. Berkeley: University of California Press. 